\title{
Associativismo no Brasil contemporâneo: dimensões institucionais e individuais ${ }^{\prime}$
}

\author{
Ligia Helena Hahn Lüchmann² \\ Carla Almeida ${ }^{3}$ \\ Luana do Rocio Taborda
}

\section{Resumo}

O trabalho analisa permanências e mudanças nos padrões de participação associativa no Brasil a partir de duas unidades de análise: a dimensão referente ao volume e às características do tecido associativo, e a dimensão do engajamento dos indivíduos em associações. A primeira explora a evolução recente do associativismo no país, que é medido pelo número, pelo perfil e pela área de atuação das associações. A segunda considera essa evolução da participação no âmbito do engajamento individual, tomando-se o número de pessoas que alega participar de associações. Para tanto, o trabalho está embasado em dados de pesquisas de opinião pública do projeto World Values Survey e nos estudos sobre Fundações Privadas e Associações Sem Fins Lucrativos no Brasil (FASFIL)/Instituto Brasileiro de Geografia e Estatística (IBGE) e sobre o Perfil das Organizações da

1 Este trabalho desenvolveu-se no âmbito do projeto de pesquisa "Mudanças e permanências nos padrões de participação política no Brasil: análise longitudinal do envolvimento político dos brasileiros (1988-2013)", apoiado pelo Programa Nacional de Cooperação Acadêmica (PROCAD) da Coordenação de Aperfeiçoamento de Pessoal de Nivel Superior (CAPES, edital no $071 / 2013$ ).

2 Ligia Lüchmann - Professora do Departamento de Sociologia e Ciência Política da Universidade Federal de Santa Catarina e pesquisadora do NPMS/UFSC vinculado à Linha de Pesquisa "Movimentos sociais, participação e democracia". Desenvolve pesquisas sobre os temas: associativismo, interfaces socioestatais, instituições participativas e teoria democrática.

3 Carla Almeida - Professora do Departamento de Ciências Sociais da Universidade Estadual de Maringá e pesquisadora do NUPPOL/UEM (Núcleo de Pesquisas em Participação Política). Desenvolve pesquisas sobre os temas: instituições participativas, democracia e participação; gênero e política.

4 Luana do Rocio Taborda-Doutoranda em Sociologia Política pela Universidade Federal de Santa Catarina, e bolsista do CNP2. É integrante do NPMS/UFSC (Núcleo de Pesquisa em Movimentos Sociais). Desenvolve pesquisas sobre os temas: associativismo, organizações da sociedade civil, interações sociedade civil - Estado e democracia.

\section{$(c)) \mathrm{Br}$}

Direito autoral e licença de uso: Este artigo está licenciado sob uma Licença Creative Commons. Com essa licença você pode compartilhar, adaptar, para qualquer fim, desde que atribua a autoria da obra, forneça um link para a licença, e indicar se foram feitas alterações. 
Sociedade civil do Instituto de Pesquisa Econômica Aplicada (IPEA). Os dados mostram que, nas últimas décadas, o Brasil testemunhou um importante crescimento na criação de associações - e que se refletiu na maior diversificação interna desse universo - embora o número de indivíduos engajados não tenha acompanhado esse crescimento. Sugerimos que a ampliação do associativismo se refletiu apenas seletivamente no plano do engajamento individual, e que o perfil específico de associações que encontrou terreno favorável ao crescimento no período, de caráter mais profissionalizado, ajuda a compreender a diferença apontada nas duas dimensões.

Palavras-chave: Associativismo. Sociedade Civil. Participação Política. Engajamento Associativo. Democracia.

\section{Introdução}

De acordo com os estudos promovidos pelo Johns Hopkins Center for Civil Society Studies ${ }^{5}$, tem ocorrido nas últimas décadas uma expansão das organizaçôes da sociedade civil nas sociedades contemporâneas. O cenário mais geral que opera, de diferentes formas, na promoção dessa expansão parece estar relacionado, entre outros fatores, à ampliaçấo das oportunidades de participação em face de processos de abertura política e às dificuldades por parte dos Estados nacionais e do conjunto das instituiçóes típicas da democracia representativa em lidar com os desafios amplificados pelos fenômenos da globalização, pluralização e complexificaçâo da sociedade. A crescente interdependência entre os Estados-Nação, o desenvolvimento dos mercados globais, as questóes ambientais que atravessam fronteiras nacionais, as novas tecnologias e meios de comunicaçáo são, entre tantos outros, aspectos da globalização que se desenvolvem vis-à-vis à propagaçáo de novas instituiçóes políticas e de organizaçóes sociais. Assim, a crescente articulaçáo de demandas locais, nacionais e transnacionais provoca mudanças sociais e políticas que desafiam a capacidade de os Estados coordenarem e mediarem os problemas e conflitos sociais.

Nesse contexto, em várias regiôes do globo, os governos têm promovido incentivos à expansão das organizaçóes da sociedade civil, seja por meio de programas que ampliam suas responsabilidades na execução de serviços públicos, seja por meio da criação de novos canais de comunicação entre sistema político e sociedade, procurando tornar o primeiro mais poroso e

5 Disponiveis em: http://ccss.jhu.edu. 
sensível às demandas sociais. Em determinados casos, como foi o do Brasil, as demandas por maior participação também partiram de organizaçôes da sociedade civil no bojo da transição de regime, que foi marcado, como veremos, por um processo de ampliação e pluralização do associativismo no país.

Pelo fato de se apresentarem, em muitos casos, como portadoras de propósitos públicos ${ }^{6}$, possuírem maior flexibilidade e conexão com os cidadãos, essas organizaçôes estão sendo cada vez mais reconhecidas e demandadas para exercer funçôes de responsabilidade social, como a prestação de serviços sociais, a capacitação de grupos que se encontram em situaçóes de vulnerabilidade, a problematização de temas e problemas sociais, a promoção de laços de confiança e integração social e a representação de interesses de diferentes grupos e classes sociais (WARREN, 2001; COHEN J; ROGERS, 1995; SALAMON; SOKOLOWSKI; HADDOCK, 2017). ${ }^{7}$

Como analisado por Salamon (2010), o repertório de termos utilizados para nominar esse campo associativo é bastante variado na literatura: organizaçóes não lucrativas, associaçóes voluntárias, sociedade civil, terceiro setor, economia social, organizaçôes não governamentais, capital social, movimentos sociais, dentre outros. Esses termos vinculam-se a diferentes teorias normativas que expressam também distintas possibilidades de conceber o papel desse campo em uma democracia. Algumas enfatizam sua importância para as relaçóes cooperativas que seriam necessárias a uma ordem democrática; outras chamam a atenção para seu papel disruptivo, no sentido de questionar os limites da ordem e promover a ampliação da democracia (LÜCHMANN, 2012).

Os termos assinalados podem abrigar também diferentes e variadas organizaçóes e instituiçôes. Alguns deles incluem hospitais, escolas, universidades, clubes, organizaçóes profissionais; outros se referem às associaçôes comunitárias, grupos ambientalistas, organizaçóes de defesa de direitos, grupos religiosos e de ajuda mútua. Enfim, esse mosaico coloca

6 Vários estudos analisam o associativismo relacionado a valores antidemocráticos como os grupos nazistas, de extrema direita, e outros grupos extremistas, como é o caso do artigo "Bad Civil Society" de Chambers e Kopstein (200I).

7 Cumpre notar que o crescente deslocamento de responsabilidades sociais para organizações da sociedade civil também tem sido analisado como um elemento integrante da desresponsabilização do Estado frente a direitos sociais no contexto de implementação, em diferentes realidades, das reformas orientadas para 0 mercado (ALMEIDA, 2006). 
dúvidas, inclusive, sobre a pertinência e a validade de enquadrar sujeitos tão diferentes em um mesmo conceito. No entanto, embora haja diversidade e desigualdades nesse campo, algumas características têm sido mobilizadas a fim de diferenciar e classificar o fenômeno do associativismo, em especial, o fato de serem organizaçóes ou associaçóes que operam de forma voluntária, autoadministrada e sem finalidades lucrativas.

No plano teórico, existe um acúmulo de estudos voltados para a compreensão do fenômeno do associativismo e que se voltam para diferentes facetas deste fenômeno. Os estudos promovidos pelo Johns Hopkins Center for Civil Society Studies, por exemplo, abordam as organizaçóes da sociedade civil a partir de uma perspectiva comparativa, buscando compreender as diferenças no que diz respeito à quantidade e à variedade das organizaçóes mapeadas em diferentes países (SALAMON, 2010; SALAMON; SOKOLOWSKI; HADDOCK, 2017). Além dessa dimensão organizacional - ou institucional -, outro conjunto de estudos na ciência política analisa os impactos do associativismo no plano da participação individual. $\mathrm{O}$ estudo de Verba, Schlozman e Brady (1995), por exemplo, nos ajuda a compreender em que medida o associativismo operaria no sentido de potencializar a participação política dos cidadáos, constituindo-se enquanto estruturas mobilizadoras do engajamento político individual.

Em diálogo com essas vertentes, e a partir de diferentes bancos de dados, este trabalho pretende explorar a evolução do engajamento associativo das brasileiras e dos brasileiros nas últimas décadas tendo em vista uma dupla dimensão relacionada, por um lado, à evolução do campo associativo, medido pelo número e crescimento dos tipos de associaçóes e, por outro, à evolução da participação associativa no âmbito individual, medida pelo número de indivíduos que alega participar, de alguma forma, de diferentes tipos de associaçóes no país. Em que pesem as dificuldades e os limites presentes nas fontes de dados utilizadas, como exposto a seguir, a análise dessas duas dimensóes nos permite sugerir que, se por um lado o Brasil vem testemunhando, em especial nas últimas décadas, uma ampliação e complexificação no plano organizacional, esse campo apresenta diferenciaçóes internas que merecem atenção, e seu crescimento parece se refletir apenas seletivamente nos dados sobre o engajamento associativo individual. 
Diante disso, sugerimos que o crescimento e a pluralização do tecido associativo no país, verificados no período, estiveram relacionados ao "momento crítico" experimentado pela sociedade brasileira no período de transição de regime, marcado pela Constituição de 1988, que imprimiu uma nova trajetória para o associativismo no país. Nas décadas seguintes, outros fatores, como a própria Reforma do Estado então desencadeada em 1990, deram seguimento a incentivos políticos e legais que levaram à criação e formalização de organizaçóes para atuar em variados programas sociais. Conforme os dados apontam, entretanto, esse fenômeno atingiu seletivamente o engajamento individual, uma vez que, nesse plano, não verificamos um crescimento significativo, embora o perfil daqueles que acusam algum vínculo com o associativismo tenha se alterado, com maior presença de mulheres e de indivíduos com menos escolarização. Sugerimos, portanto que, entre outras variáveis, a conformação do campo das associaçóes, como a localização, o tamanho, o perfil dos seus trabalhadores e voluntários, e as áreas de atuação, são elementos importantes para a compreensão do perfil dos indivíduos que acusam participar de associaçóes.

O trabalho está dividido em quatro seçôes, além desta introdução e das notas conclusivas. A primeira seção apresenta as fontes de dados e os procedimentos utilizados para os fins desta reflexão; a segunda, apresenta as referências teóricas com as quais dialogamos no exame das duas dimensôes da participação propostas por esse trabalho; a terceira, apresenta os dados da evolução e as características das associaçóes nos períodos mais recentes da trajetória do país; por fim, a quarta seção está dedicada à apresentação dos dados do envolvimento associativo dos brasileiros e brasileiras em uma perspectiva individual.

\section{Fontes e procedimentos metodológicos}

No que diz respeito ao levantamento das associaçóes existentes no país, tomamos como referência: o estudo das Fundaçóes Privadas e Associaçóes Sem Fins Lucrativos no Brasil (FASFIL), com o foco na sua última edição (2010); e os dados da pesquisa do IPEA intitulada Perfil das Organizaçôes da Sociedade Civil no Brasil $(2018)^{8}$. A primeira pesquisa foi realizada pelo

8 Para facilitar a identificação dos dois estudos no texto, fala-se em FASFIL para reportar à pesquisa do IBCEE, ou 
Instituto Brasileiro de Geografia e Estatística (IBGE) em parceria com o Instituto de Pesquisa Econômica Aplicada (IPEA), a Associação Brasileira de Organizaçóes Não Governamentais (ABONG) e o Grupo de Institutos, Fundaçóes e Empresas (GIFE), contando com participação da Secretaria Geral da Presidência da República. O relatório produzido apresenta um panorama quantitativo das associaçóes segundo suas áreas e subáreas de atuação, trazendo informações sobre a sua distribuição no território nacional, tempo de existência, porte e perfil dos trabalhadores das FASFIL - relativo ao número de empregados, à remuneração, ao gênero e ao nível de escolaridade no período de 2006 a 2010. A segunda pesquisa, de publicação recente do IPEA, segue a mesma metodologia da anterior, buscando apresentar dados comparáveis com a FASFIL ${ }^{9}$ para o período de 2011 a 2016.

Em que pese o fato de ser a principal fonte de dados no plano nacional, três aspectos são aqui dignos de nota em relaçáo a esses dados. Em primeiro lugar, o aspecto da definição. Visando a construir estatísticas comparáveis internacionalmente, o estudo das FASFIL aderiu à definição elaborada pela Divisão de Estatística da Organização das Naçóes Unidas (ONU), em conjunto com a Universidade John Hopkins, seguindo critérios baseados, entre outros, em registros institucionais e formais. Isso implica em um recorte que limita o campo do associativismo no país, ao não incorporar dados de uma multiplicidade de grupos, associaçóes e movimentos que não apresentam natureza legal.

Além disso, temos também que considerar alguns problemas referentes à classificação do universo por áreas e subáreas de atuação. O estudo classificou o campo das FASFIL em dez grupos (e respectivos subgrupos) temáticos, quais sejam: habitação; saúde; cultura e recreação; educação e pesquisa; assistência social; religião; associaçóes patronais e profissionais; meio ambiente e proteção animal; desenvolvimento e defesa de direitos; e

em OSCs, para reportar à pesquisa do IPEA. Ainda, nos casos em que se faz referência a ambos os estudos, utiliza-se FASFIL/OSCs.

9 Conforme aponta Lopez (2018, p. 10), os dados desse segundo banco: "Avançam em cruzar mais informações do que as que existiam até então. Incorpora-se o esforço nacional anterior do IPEA com o IBGE, que consolidou critérios de identificação e classificação de OSCs na pesquisa Fundações Privadas e Associações sem Fins Lucrativos no Brasil (FASFIL), cuja última edição utilizou dados de 2010. A adoção desses critérios permite comparar os resultados apresentados com estatísticas de outras publicações". 
outras. Algumas questôes chamam a atenção para esta classificação, como por exemplo, a amplitude da área da religião ${ }^{10}$, englobando igrejas, templos e paróquias, e a caracterizaçáo das subáreas no campo dos Direitos Humanos, que incorporam as associaçóes de moradores e os centros comunitários, conformando um mosaico de organizaçóes que apresentam diferentes perfis e objetivos. Ademais, para fins de operacionalização, a classificação identificou as organizaçóes a partir uma principal e única finalidade. Assim, esse recorte promove um outro tipo de viés ao não reconhecer a dimensão multifocal de muitas organizaçóes, muito embora seja compreensível a dificuldade perante a complexidade na identificação das múltiplas áreas de atuação associativa."

Por último, são dignas de nota as mudanças metodológicas transcorridas no decorrer do tempo. Nas três ediçóes da FASFIL (2002, 2006 e 2010), os dados foram elaborados com a preocupação de que fossem diretamente comparáveis, embora a edição de 2010 traga uma metodologia reformulada que procura incorporar critérios novos para a seleção de unidades ativas do cadastro do CEMPRE ${ }^{12}$ retirando, do universo das entidades sem fins lucrativos, “[...] aquelas que não atendiam, simultaneamente, aos cinco critérios que as definem e caracterizam, quais sejam: organizaçóes institucionalizadas, privadas, não distribuidoras de lucro, autoadministradas e voluntárias" (IBGE, 2012, p. 14). Assim, juntamente com outras organizaçóes ${ }^{13}$, os sindicatos foram excluídos das FASFIL,

10 "Encontram- se agrupadas nesta categoria: ordens religiosas, templos, paróquias, pastorais, centros espíritas, entre outras. As demais instituições de origem religiosa que desenvolvem outras atividades e que têm personalidade jurídica própria (hospitais, colégios, creches, por exemplo) estão classificadas de acordo com sua atividade fim. Por outro lado, cabe assinalar que essas entidades, além de desenvolverem atividades confessionais, ocupam novos espaços de debate e deliberação de políticas públicas, como os conselhos, conferências e grupos de trabalhos governamentais" (IBCE, 20/2, p.3I).

II O relatório reconhece essa "dificuldade de apreender de forma abrangente a finalidade das instituições, no caso daquelas que atuam em mais de uma atividade" (IBGE, 20I2, p. 23).

12 "O CemPre (Cadastro Central de Empresas) - - $m$ se referm estas datas? 2006.e IBCE cobre o universo das organizações formais, ou seja, inscritas no Cadastro Nacional da Pessoa Jurídica (CNPJ), da Secretaria da Receita Federal, que no ano de referência declararam exercer atividade econômica no Território Nacional às fontes de atualização do CemPre: pesquisas econômicas estruturais do IBCE e registros administrativos do Ministério do Trabalho e Emprego. O CemPre abrange organizações de toda natureza jurídica: órgãos da administração pública, entidades empresariais, entidades sem fins lucrativos, pessoas físicas e organizações internacionais e outras instituições extraterritoriais" (IBCE, 20/2, p. 12).

13 Caixas escolares e similares; Partidos políticos; Sindicatos, federações e confederações; Condomínios; Cartórios; Sistema S; Entidade de mediação e arbitragem; Comissão de conciliação prévia; Conselhos, fundos e consórcios municipais; e Cemitérios e Funerárias. 
Associativismo no Brasil contemporâneo: dimensões institucionais e individuais) | Lígia Helena Hahn Lüchmann; Carla Almeida; Luana do Rocio Taborda

causando uma perda considerável nos dados sobre o fenômeno do associativismo no país.

As considerações metodológicas colocadas quanto à pesquisa das FASFIL também podem ser atribuídas ao caso da pesquisa do IPEA. A principal diferenciação dessa segunda com a anterior seria quanto à fonte dos dados: a pesquisa do IBGE tomou como referência a Relação Anual de Informaçóes Sociais do Ministério do Trabalho (RAIS-MTE), e a pesquisa do IPEA é complementada pelas informaçóes constantes no Cadastro Nacional de Pessoas Jurídicas (CNPJ) da Secretaria da Receita Federal (SRF), o que resultou em número bastante superior de OSCs mapeadas em comparação com o estudo do $\mathrm{IBGE}^{14}$.

No que diz respeito à dimensão individual da participação em associaçóes, tomamos como base os dados relativos às rodadas de 1991, 2006 e 2014 do World Values Survey (WVS) para o Brasil ${ }^{15}$. Neste banco, obtivemos dados para as seguintes modalidades associativas: Associaçôes ou Organizações Religiosas; Associaçóes Esportivas ou Recreacionais; Associaçôes Sindicais; Associações Ambientais; Associaçóes Profissionais; Associações na área de Artes, Músicas ou Educacionais; Partidos Políticos; Associaçóes Filantrópicas; Associaçóes de Consumidores; Associaçóes ou Grupos de Ajuda Mútua e Outras associaçóes.

14 A escolha pela realização de um comparativo entre ambos os estudos, em que pesem suas diferenciações, seria a aproximação metodológica e o fato de se tratarem das principais pesquisas existentes sobre a dimensão institucional das FASFIL/OSCs no Brasil. Justifica-se a escolha considerando que ambas as pesquisas foram feitas visando à construção de comparativos tanto com pesquisas anteriores quanto com estudos internacionais que utilizam a metodologia da John Hopkins/ONU. Assim, o comparativo dos dados, principalmente quanto à distribuição, características e OSCs ativas em termos percentuais, apresenta-se de grande valia para avançarmos na compreensão sobre os contornos do associativismo formal no país.

15 Cabe pontuar que, nas três rodadas da World Values Survey (2014) que são aqui utilizadas, há uma leve discrepância entre a forma como a questão foi elaborada, bem como quanto às possibilidades de resposta. Em 199I, era pedido que o respondente indicasse, a partir de uma lista de associações que lhe era mostrada, aquelas a que ele fazia parte (Belong to). Já em 2006 e 2014, era lida uma lista de associações, entre as quais o respondente deveria dizer se era participante ativo ou inativo ou se não participava, de cada qual. Assim, reconhecemos que esta pequena mudança pode ter influências nas mudanças de percentuais (como no caso das religiosas, principal diferenciação de percentual), embora não invalide os efeitos comparativos aqui propostos. Isso porque, argumentamos, dentre as três ondas, é possivel medir a participação e não participação. Com a recodificação dos dados de 2006 e 2014, juntando participantes ativos e inativos, temos um índice daqueles que disseram participar e daqueles que não, assim como em 1991 - que não foi necessário recodificar. Dessa forma, acreditamos que os dados refletem o engajamento individual, já que os anos de 2006 e 2014 mensuram o mesmo que em 1991: o percentual de participação individual nos diferentes tipos associativos. 
Considerando que o WVS deixa de fora algumas modalidades associativas que nos parecem muito importantes para a realidade latino-americana, como as associaçóes de bairro ou comunitárias, também fizemos uso de um banco construído a partir da junção de dados de opinião pública contidos no Centro de Estudos de Opinião Pública (CESOP) da Universidade Estadual de Campinas (Unicamp) ${ }^{16}$. Essa segunda fonte assume uma função secundária e complementar na nossa análise, de modo a contemplarmos dados sobre o associativismo náo disponibilizados pelo WVS.

A despeito de todos os cuidados que devem ser tomados em relação às fontes utilizadas, o trabalho que apresentamos tem o mérito de sistematizar os dados disponíveis sobre o associativismo e estabelecer uma comparação com os dados sobre engajamento individual, buscando, com isso, uma análise mais integrada do fenômeno associativo brasileiro.

\section{Associativismo e engajamento individual}

Embora as especificidades de cada país, o estudo de Salamon, Sokolowski e Haddok (2017) aponta alguns padróes explicativos para ajudar a entender as diferenças encontradas em termos de tamanho, forma e estrutura de funcionamento das organizaçóes da sociedade civil em perspectiva comparativa internacional. Em diálogo crítico com as teorias "da preferência" 17 e "do sentimento"18, o estudo procura explicar esses padrôes

16 Os bancos de dados disponíveis utilizados - e os anos das coletas - são: CESP-003222 (1993), Latinobarômetro (1996, 1998, 2000, 2007), ESEB (2002), e Barômetro das Américas (2006, 2008, 2010, 2012, 2014). Os dados são referentes às seguintes modalidades associativas: sindicatos, associações profissionais, associações na área do meio ambiente, associações comunitárias/bairros, associações de pais e mestres e associações religiosas. Convém destacar que, nesse conjunto de dados, as diferentes bases continham questões distintas acerca do envolvimento dos individuos em modalidades associativas, de modo que foram necessárias recodificações, a fim de possibilitar a construção de nossa análise longitudinal. Diante disso, procuramos respeitar, nas recodificações, os sentidos das perguntas e as categorias de respostas, tendo em vista as similaridades entre os dados deste banco e aqueles de World Values Survey (2014) para os anos em que dispomos de ambas as informações. Agradecemos aos bolsistas PROCAD Filipe Vicentini Faeti, Milena Cristina Belançon, Ana Paula Brito Maciel, Bruno Henrique Costa Dezotti (UEM), Tayná Teixeira Chaves Trindade, Luana do Rocio Taborda, Ana Luzia Garcia (UFSC), Bruno Portari e Vinicius Sturari (UNESP), e ainda a Danilo César Macri Lazare (UEM) pela contribuição na coleta de dados. Agradecemos, também, a Gabriel Ávila Casalecchi (UFSC) pela sistematização e compilação de todos esses bancos.

17 Com base nas escolhas racionais de atores que maximizam as suas preferências por bens ou serviços.

18 Baseadas, em uma perspectiva secular, na ideia de virtude civica, encontrada especialmente no republicanismo cívico, no comunitarismo e no conceito de "capital social"; seja em uma perspectiva religiosa, ancorada 
por meio das distintas constelaçóes de relações de poder existentes entre os diferentes grupos e instituiçôes socioeconômicas, incluindo as elites políticas, a configuração das classes sociais e as instituiçóes sociais e políticas por meio das quais esses grupos se articulam e expressam os seus interesses e suas perspectivas. De acordo com os autores, por exemplo, se a religião opera na constituição da sociedade civil, isso ocorre menos pela sua influência no plano dos sentimentos, e mais por meio de suas estruturas institucionais, de suas relaçóes de poder e de hierarquias, da competitividade por ampliar o quadro de adeptos, de sua maior ou menor capilaridade social, política e cultural.

Apoiando-se em referências do neoinstitucionalismo histórico, Salamon, Sokolowski e Haddok (2017) argumentam que o tamanho e os contornos da sociedade civil são fundamentalmente moldados por constelaçóes particulares de desenvolvimento e de relaçóes de poder entre os diferentes grupos, classes e instituiçóes sociais, que são filtradas por uma variedade de fatores contextuais em "momentos críticos" na história das diferentes sociedades, e que se solidificam durante períodos prolongados. Os momentos críticos, ou os "turning points", são pontos de inflexão que redirecionam trajetórias em longo prazo, diferentemente de se constituírem em momentos de mudança ou desvios temporários (TERUYA; HSER, 2010). De acordo com Turabian (2017, p. 1), “'Turning point' is a point of inflection, or stage or milestone or change or a decisive, crucial, radical, important, critical, historical or key moment. It is a decisive "transition".

Nesse enquadramento, o fim da ditadura militar pode ser apontado como um dos "momentos críticos" no processo histórico ${ }^{19}$ de desenvolvimento da sociedade civil no Brasil, constituindo-se em um contexto de mudanças importantes que inauguram um período de transição à

na premissa de que os sentimentos de filantropia ou altruismo são elementos centrais na constituição do associativismo.

19 Há controvérsias, na literatura, sobre perspectivas "emergentes" da sociedade civil brasileira, datando os anos de 1970 como inauguradores na constituição de um associativismo denso e plural no país (AVRITZER, 1997). Essa tese de uma "emergência tardia da sociedade civil no Brasil" é contestada por Gurza Lavalle e Szwako (2015), autores que demonstram que havia, pelo menos desde o século XIX, a presença de diversas organizações no Brasil - a exemplo das associações de auxílio ou socorro mútuo, religiosas, das revoltas e das organizações abolicionistas. 
democracia, ampliando o leque de oportunidades de criação de novas associaçóes, legando inovaçóes com potencial de permanência no tempo. Podemos considerar, assim, que se trata de momentos em que os fatores estruturais - de natureza política, econômica ou cultural - afrouxam-se na sua capacidade de constranger a ação política dos atores, possibilitando inovaçóes que conformam novas constelaçóes de relaçóes de poder. Como veremos mais adiante, os dados de pesquisas nacionais (FASFIL, 2012; LOPEZ, 2018) indicam um crescimento constante das associaçóes no país a partir de 1970. De acordo com o estudo do IPEA (LOPEZ, 2018 , p. 141), "em todas as regióes náo passa de $5 \%$ o total de OSCs fundadas até 1970".

Nas décadas seguintes à promulgação da Constituição de 1988, marco importante do momento crítico pós-ditadura, o ritmo no crescimento das associaçôes parece ter se mantido, como analisado por Landim (2002). De acordo com a autora, os anos de 1990 apresentam um crescimento de organizaçóes de base empresarial, além das assistenciais, que também alteram as suas práticas e o seu discurso no registro da defesa de direitos de cidadania. Nesse sentido, o Brasil parece seguir o movimento mais amplo que ocorre no plano internacional mencionado anteriormente.

Diante disso, podemos perguntar "se e como" as mudanças na configuração do campo associativo impactam o engajamento político individual. Por essa dimensão analítica, o estudo de Verba, Schlozman e Brady (1995) considera que a participação dos indivíduos em organizaçóes da sociedade civil é fundamental para a produção de diagnósticos mais adequados para o problema da "equidade da voz política", entendida por eles como a capacidade de os indivíduos e grupos influenciarem as decisóes públicas. Os autores apontam pelo menos três fatores que operam no engajamento político dos indivíduos, quais sejam: os fatores de ordem socioeconômica - os recursos (tempo, renda, escolaridade); os de ordem psicológica (vontade, compromisso, interesse por política, valores cívicos); e os relacionados aos laços sociais que operam nos processos de recrutamento por meio de redes formais e informais. Sua pesquisa sobre a sociedade americana identificou, por exemplo, disparidades significativas e duradouras na expressão da "voz política" naquele país (VERBA; SCHLOZMAN; BRADY, 2012). Segundo dados de séries históricas, o estudo constatou que os recursos 
que possibilitam o engajamento político (motivação, tempo, dinheiro, habilidades e inserção em redes) se retroalimentam, condicionando-se mutuamente, gerando desigualdades que se reproduzem por geraçóes. Por isso, os processos que propiciam a "voz política" não apenas expressam, mas também podem reproduzir desigualdades sociais. Estudos qualitativos têm demonstrado, por exemplo, que comparados com grupos de classe média e mais escolarizados, os setores de baixa renda tendem a se considerar pouco eficazes na política. A exclusão socioeconômica se traduz, também, em exclusão subjetiva (GARCÍA-ESPÍN; GANUZA, 2017).

Nesse sentido, os cidadãos com menores níveis de renda e educação seriam menos propensos ao engajamento, gerando a sub-representaçáo de determinados grupos em termos de voz política. Verba, Schlozman e Brady (1995) enfatizam que os atributos socioeconômicos ajudam a explicar outras diferenças em termos de engajamento, como as relacionadas à raça e a gênero. Seus dados para os Estados Unidos mostram que, precisamente, são os homens brancos os maiores acumuladores dos recursos socioeconômicos que permitem o engajamento, comparados com mulheres ou homens latinos.

Tomando o caso de países latino-americanos, Ribeiro e Borba (2015) também confirmam a importância de variáveis sociodemográficas para o engajamento político. Segundo os dados da pesquisa - a qual considerou Brasil, Chile, Argentina e Uruguai -, quanto mais "centralizado" estiver o indivíduo, ou seja, quanto mais ele pertencer aos grupos que ocupam posiçôes vantajosas na sociedade em termos de renda e escolaridade, maior sua propensão ao engajamento participativo.

Ribeiro e Borba (2015) também procuraram verificar a validade, para o caso da América Latina, das "teses pós-materialistas" que alegam estar ocorrendo importantes mudanças nos valores normativos dos cidadãos das democracias estabelecidas, com impactos nos seus padróes de engajamento político (INGLEHART; WELZEL, 2005). Nessa perspectiva, as sociedades pós-industriais estariam experimentando um declínio nas formas tradicionais de engajamento político, como comparecimento eleitoral e a participação em sindicatos e igrejas e, ao mesmo tempo, os cidadãos estariam mais críticos às instituiçóes democráticas e seriam portadores, sobretudo, de demandas de novo tipo, denominadas "pós-materiais", como igualdade de gênero e defesa do meio ambiente (DALTON; WELZEL, 2014). 
Para os casos estudados, Ribeiro e Borba (2015) confirmam em parte as teses pós-materiais, mas ressaltam que, em todos os países da América Latina investigados, indivíduos engajados em organizaçóes de defesa de meio ambiente, consideradas uma forma pós-material de engajamento, tendem também a participar de modalidades tradicionais, como sindicatos, partidos e associaçóes profissionais. Assim, parece que os padrôes de engajamento político individual também são determinados pelas peculiaridades que marcam e constituem as diferentes sociedades.

Cumpre ainda notar que, se os atributos socioeconômicos ajudam a explicar as diferenças em termos de engajamento individual, outras variáveis intercedem nesse fenômeno, com destaque, aqui, à importância das associaçóes. Vários autores têm apontado para os potenciais de inclusão política do campo associativo ${ }^{20}$. De acordo com Macpherson (1978, p. 106), por exemplo, o rompimento com o ciclo vicioso da desigualdade e da não participação pode ocorrer, entre outras possibilidades, por meio de organizaçóes comunitárias, ou de associaçóes que exercem pressão para a mudança das condiçóes sociais, atraindo para a participação política, sobretudo, os setores mais empobrecidos da populaçáo e que "estiveram por muito tempo politicamente apáticos".

Em diálogo com esses estudos, apresentamos a seguir um panorama da participaçáo associativa dos brasileiros tendo em vista articular dados relativos a duas unidades de análise, quais sejam, os dados relativos à evolução e a características das associaçóes, e os referentes ao engajamento individual em associaçôes.

\section{O campo do associativismo no Brasil contemporâneo}

No caso brasileiro, a literatura sobre o associativismo nas últimas décadas mostra que houve uma importante ampliação e diversificação desse campo a partir da década de 1970. Tal fenômeno teria sido decorrente não apenas do processo de urbanização e industrialização, como também do contexto das mobilizaçóes pró-democracia e de "abertura política" que

20 Entre eles: Warren, 200I; Fung, 2003; Cohen e Rogers, 1995; Young, 1995. Vide Lüchmann, 2012 e 2014. 
marcou a década de 1980 do país ${ }^{21}$. Naquele contexto, organizaçôes profissionais e sindicais, associações de moradores, grupos de mulheres, Comunidades Eclesiais de Base, organizaçóes ambientalistas, grupos de educação popular, movimentos indígenas e antirracistas foram, entre muitos outros, exemplos do revigoramento associativo do país. Podemos sugerir, assim, que a transição se configurou, como já mencionado anteriormente, em um "momento crítico" que possibilitou a emergência de novos atores, resultando em uma maior pluralizaçáo e complexificaçáo do campo associativo.

$\mathrm{Na}$ década de 1990, o campo associativo brasileiro continuou a sofrer inovaçôes impulsionadas por processos que, em parte foram decorrentes da transição, em parte tiveram origem em fatores mais amplos ou externos ao país. Por um lado, o processo de globalização e a realização de inúmeras Conferências Mundiais das Naçóes Unidas ${ }^{22}$ deu visibilidade à atuação das Organizaçôes Não Governamentais (ONGs), além da ampliação das interlocuçóes entre diferentes movimentos sociais em escala internacional, colocando novos desafios analíticos que dessem conta das articulaçóes de vários fóruns locais, regionais, nacionais e internacionais. Por outro lado, no plano nacional, surgiram novas ONGs em várias áreas temáticas respondendo, em larga medida, ao estímulo de formalização e qualificação exigidos para a participação de organizaçôes sociais na execução de políticas públicas em um contexto de Reforma do Estado, “[...] que previa transferir as responsabilidades do Estado para a sociedade e inserir as ONGs no projeto de colaboração em políticas compensatórias” (TEIXEIRA, 2008, p. 107). Para além daquelas organizações mais identificadas com a nomenclatura "ONGs", um conjunto de associações, com perfil muito variado, foi criado e/ou formalizado em várias localidades do país em função dos incentivos legais e políticos então abertos para sua colaboração e participaçáo junto à execuçáo de programas sociais e políticas públicas.

21 De acordo com Santos (1993), se em 1940 o país apresentava 31,2\% da população no espaço urbano, em 1980 este número passou para 67,6\%. Respaldado em dados de São Paulo e Rio de Janeiro, o autor mostra que o período de 1970 a 1986 foi o de maior crescimento do associativismo civil no país.

22 Conferências: Meio Ambiente e Desenvolvimento (Rio/92); Direitos Humanos (Viena/93); População e Desenvolvimento (Cairo/94); Desenvolvimento Social (Copenhague/95); Mulher (Beijing/95); Hábitat II (Istambul/96). Sobre a relação entre sociedade civil e as Nações Unidas, vide Vieira, 200 I. 
É digno de nota também mencionar que, desde a Constituição de 1988, o Brasil testemunhou um importante processo de inovação institucional, com a criação, crescente no período posterior, de novas instâncias de mediação entre Estado e sociedade civil na formulação e gestão de políticas públicas, a exemplo dos Conselhos Gestores, o que agiu como incentivo à expansão, ou ao menos à formalização, de organizações sociais com interesse de incidir nos processos decisórios daquelas políticas.

$\mathrm{O}$ crescimento do associativismo tem sido atestado pelas pesquisas sobre as FASFIL promovidas pelo IBGE/IPEA (IBGE, 2012), e sobre o Perfil das Organizaçóes da Sociedade Civil (OSCs) pelo IPEA (LOPEZ, 2018), constituindo-se como referências de dados e análises sobre a sociedade civil no país. A pesquisa do IBGE apresenta informaçóes sobre o universo dessas organizaçóes nos períodos de 2002, 2005 e 2010. Sua terceira edição (2010) apresenta os dados das organizações segundo áreas e subáreas de atuação, trazendo também informações sobre o perfil dos trabalhadores das FASFIL e sobre a sua distribuição no território nacional (IBGE, 2012). A pesquisa do IPEA atualiza esses dados para 2016, conforme salientado anteriormente.

Ambas as pesquisas adotaram cinco critérios para a coleta de dados e inclusão das organizaçóes na denominação FASFIL/OSCs, quais sejam: a) serem organizaçóes privadas, não integrantes do aparelho de Estado; b) sem fins lucrativos, isto é, organizaçôes que não distribuem eventuais excedentes entre os proprietários ou diretores e que não possuem como razão primeira de existência a geraçáo de lucros; c) institucionalizadas, isto é, legalmente constituídas; d) autoadministradas ou capazes de gerenciar suas próprias atividades; e) voluntárias, na medida em que podem ser constituídas livremente por qualquer grupo de pessoas. De acordo com os estudos, além de seguirem a classificação do Johns Hopkins Center for Civil Society Studies, esses critérios de conceituação do que são as FASFIL/OSCs seguem também a diferenciação entre associações, fundaçóes e organizaçôes religiosas que está impressa no novo Código Civil. ${ }^{23}$

23 Segundo a pesquisa do IBCE (20/2, p. 13): "As associações, de acordo com o art. 53 do novo Código regido pela Lei $n^{\circ}$ 10.406, de 10 de janeiro de 2002, constituem-se pela união de pessoas que se organizam para fins não econômicos. As fundações são criadas por um instituidor, mediante escritura pública ou testamento, a partir de uma dotação especial de bens liures, especificando o fim a que se destina, e declarando, se quiser, a 
Considerando essa definição, o número total de FASFIL no Brasil alcançou, em 2010, 290,7 mil, representando 5,2\% do total de 5,6 milhóes de entidades públicas e privadas - lucrativas e não lucrativas - que compunham o Cadastro Central de Empresas (Cempre), do IBGE (IBGE, 2012). Já o estudo do IPEA (2018) mapeou um número bastante superior de OSCs: em 2016 havia um total de 820 mil organizaçóes da sociedade civil (OSCs) ativas, segundo as fontes da Relação Anual de Informaçóes Sociais (RAIS) do Ministério do Trabalho e Emprego (MTE) e do Cadastro Nacional de Pessoas Jurídicas (CNPJ), da Secretaria da Receita Federal (SRF). O estudo apresenta os dados relativos aos períodos de criação dessas organizaçóes, conforme ilustra a Tabela 1 .

Tabela I - OSCs segundo faixas de ano de criação (Brasil, 2016)*

\begin{tabular}{cccccc}
\hline \multicolumn{5}{c}{ OSCs } \\
\hline $\begin{array}{c}\text { Faixas de ano de } \\
\text { fundação }\end{array}$ & Total & $\begin{array}{c}\text { Percentual } \\
\mathbf{( \% )}\end{array}$ & $\begin{array}{c}\text { Faixas de ano } \\
\text { de fundação }\end{array}$ & Total & Percentual (\%) \\
Até 1970 & 28.579 & 3,50 & $\mathbf{2 0 1 \mathbf { I }}$ & 29.663 & 3,60 \\
De 1971 a 1980 & 72.466 & 8,80 & $\mathbf{2 0 1 2}$ & 25.722 & 3,10 \\
De 1981 a 1990 & 88.147 & 10,70 & $\mathbf{2 0 1 4}$ & 28.113 & 3,40 \\
De 1991 a 2000 & 201.389 & 24,60 & $\mathbf{2 0 1 5}$ & 23.835 & 3,00 \\
De 2001 a 2010 & 277.452 & 33,80 & $\mathbf{2 0 1 6}$ & 19.949 & 2,90 \\
& Total & $\mathbf{8 2 0 . 1 8 6}$ & $\mathbf{1 0 0 , 0 0}$ & & \\
\hline
\end{tabular}

*Elaboração do IPEA.

Fonte: Adaptada de Lopez (2018, p. 140).

Como podemos perceber, das organizaçóes identificadas - portanto, aquelas ativas em 2016 -, a maior parte é relativamente recente no país, de forma que mais de $50 \%$ delas foram criadas a partir de 2001, somando 429.604 mil entidades. Por outro lado, 35\% das OSCs ativas surgiram no período de 1980 e 2000, o que chama atenção para a capacidade de articulação e continuidade das associaçóes criadas naquele momento mais associado à transição política. Também chama a atenção o fato de que, entre 
2011 e 2016, a taxa de crescimento das OSCs no Brasil tem se mantido em torno de 3\%, o que demonstra crescimento desacelerado considerando períodos anteriores, dado já apontado pela pesquisa do IBGE (2012).

A distribuição das OSCs pelo território nacional segue, em linhas gerais, a dimensão populacional, segundo região, com exceção da região sul do país, em terceiro lugar no número de OSCs, e acomodando 19,3\% das entidades em um quadro populacional que congrega $14,3 \%$ da população do país, possuindo o maior quantitativo de OSCs por indivíduo. O estudo do IPEA (LOPEZ, 2018) também analisa a concentração de OSCs nas capitais, apontando que: "Há equivalência entre a proporção da população que vive e as OSCs que atuam nas capitais dos estados. Por isso, não há concentração de OSCs nas capitais, as quais abrigam $24 \%$ da população brasileira e 22,5\% das OSCs" (LOPEZ, 2018, p. 21) 24.

Tabela 2 - Distribuição das OSCs segundo as Regiões do país*

\begin{tabular}{lllll}
\hline Região & Total de OSC 2016 & $\mathbf{\%}$ & Total Populacional (Censo 2010) & $\%$ \\
\hline Sudeste & 325.376 & $\mathbf{3 9 , 7}$ & 86.356 .952 & 41,9 \\
Nordeste & 205.300 & $\mathbf{2 5 , 0}$ & 56.915 .936 & 27,6 \\
Sul & 157.898 & $\mathbf{1 9 , 3}$ & 29.439 .773 & 14,3 \\
Norte & 67.370 & $\mathbf{8 , 2}$ & 17.707 .783 & 8,6 \\
$\begin{array}{l}\text { Centro- } \\
\text { oeste }\end{array}$ & 64.242 & $\mathbf{7 , 8}$ & 15.660 .988 & 7,6 \\
\hline
\end{tabular}

*Elaboração do IPEA.

Fonte: Adaptada de Lopez (20/8, p. 27).

Outro dado interessante apresentado pelo relatório do IPEA diz respeito à existência de um paralelo entre o Índice de Desenvolvimento

24 Há, porém, importantes disparidades segundo os Estados. Na região Norte, por exemplo, o Amazonas tem 2,9 OSCs por mil habitantes, e Tocantins 5,2; no Nordeste. Alagoas em 2,5 e no Piaui 5,2; Já nos três Estados de Santa Catarina, a diferença é grande entre Paraná (4,7) e Santa Catarina (6,5), estado este com o maior indice de OSCs por indivíduos do país. Quanto às capitais, os dados da pesquisa do IPEA indicam equivalência entre o contingente populacional e número de OSCS, visto que, de forma aproximada, I em cada 4 brasileiros vive em capitais, e I em cada 4 OSCs também. Os casos mais destoantes seriam Manaus (2,5 OSCs por mil habitantes) e Florianópolis, com maior proporção de Organizações da Sociedade Civil por habitantes dentre as capitais $(7,9)$. 
Humano (IDH) e o número de OSCs. De maneira geral, os estudos partem do pressuposto de que as OSCs contribuem para o desenvolvimento em diferentes frentes sociais e econômicas, daí sua maior presença influenciando/coincidindo com um IDH mais alto ${ }^{25}$. De maneira geral, os dados corroboram essa análise, à exceção das organizações da subárea de "defesa de direitos e interesses", que apresentam maior concentração per capita em regiôes com IDH inferior, conforme mostraremos a frente.

Vejamos, agora, a distribuição por área de atuação das associações. Ainda que argumentos conclusivos requeiram outros estudos, de caráter inclusive qualitativo, dados referentes à área de atuação das associaçóes ajudam a compreender quais temas ganharam ou perderam relevância na agenda dos atores coletivos e quais interesses eles expressam. São dados que nos ajudam a entender, portanto, dimensôes da "voz política" que emana do fenômeno associativo no Brasil.

Tabela 3 - Número de OSCs segundo finalidade de atuação no Brasil (2016)*

\begin{tabular}{lcc}
\hline \multicolumn{1}{c}{ Classificação das entidades sem fins lucrativos } & $\mathbf{2 0 1 6}$ & $\mathbf{( \% )}$ \\
\hline Total & $\mathbf{8 2 0 . 1 8 6}$ & $\mathbf{1 0 0 , 0}$ \\
Saúde & $\mathbf{6 . 8 4 1}$ & $\mathbf{0 , 8}$ \\
Hospitais & 2.646 & 0,3 \\
Outros serviços de saúde & $\mathbf{4 . 1 9 5}$ & $\mathbf{0 , 5}$ \\
Cultura e recreação & $\mathbf{7 9 . 9 1 7}$ & $\mathbf{9 , 7}$ \\
Cultura e arte & 24.671 & 3,0 \\
Esportes e recreação & 55.246 & 6,7 \\
Educação e pesquisa & $\mathbf{3 9 . 6 6 9}$ & $\mathbf{4 , 8}$ \\
Educação infantil & 8.381 & 1,0 \\
Ensino fundamental & 9.509 & 1,2 \\
Ensino médio & 1.941 & 0,2 \\
Educação superior & 3.242 & 0,4 \\
Estudos e pesquisas & 1.268 & 0,2 \\
Educação profissional & 972 & 0,1 \\
Outras formas de educação/ensino & 6.208 & 0,8 \\
Atividades de apoio à educação & 8.148 & 1,0 \\
\hline
\end{tabular}

25 Em Almeida, D'Andrea e De Lucca (2008), os autores, em estudo sobre duas comunidades periféricas de São Paulo, procuram demonstrar como a presença de associações pode influenciar positivamente na diminuição dos niveis de exclusão social experimentados pela população. 


\begin{tabular}{lcc}
\hline \multicolumn{1}{c}{ Classificação das entidades sem fins lucrativos } & $\mathbf{2 0 1 6}$ & $\mathbf{( \% )}$ \\
\hline Assistência social & $\mathbf{2 7 . 3 8 3}$ & $\mathbf{3 , 3}$ \\
Assistência social & 27.383 & 3,3 \\
Religião & $\mathbf{2 0 8 . 3 2 5}$ & $\mathbf{2 5 , 4}$ \\
Religião & 208.325 & 25,4 \\
Associações patronais e profissionais & $\mathbf{2 2 . 2 6 1}$ & $\mathbf{2 , 7}$ \\
Associações empresariais e patronais & 7.985 & 1,0 \\
Associações profissionais & 14.276 & 1,7 \\
Desenvolvimento e defesa de direitos e interesses & $\mathbf{3 3 9 . 1 0 4}$ & $\mathbf{4 1 , 3}$ \\
Defesa de direitos e interesses - múltiplas áreas & 41.611 & 5,1 \\
Associações de pais, professores, alunos e afins & 40.697 & 5,0 \\
Associação de moradores & 33.460 & 4,1 \\
Associações patronais e profissionais & 29.882 & 3,6 \\
Centros e associações comunitárias & 20.630 & 2,5 \\
Cultura e recreação & 14.091 & 1,7 \\
Saúde, assistência social e educação & 13.837 & 1,7 \\
Religião & 5.448 & 0,7 \\
Meio ambiente e proteção animal & 3.268 & 0,4 \\
Desenvolvimento rural & 2.288 & 0,3 \\
Defesa de direitos de grupos e minorias & 1.406 & 0,2 \\
Outras formas de desenvolvimento e defesa de direitos & 132.486 & 16,2 \\
Outras atividades associativas & $\mathbf{7 7 . 5 5 0}$ & $\mathbf{9 , 5}$ \\
Associações em atividades não especificadas anteriormente & 77.550 & 9,5 \\
Outras organizações da sociedade civil & 19.136 & 2,3 \\
\hline
\end{tabular}

*Elaboração do IPEA.

Fonte: Adaptada de Lopez ( 2018, p. 38-39).

Como podemos perceber, dois são os principais grupos de OSCs existentes: o grupo de desenvolvimento e defesa de direitos e interesses e o grupo das organizaçóes religiosas, representando, juntos, seis em cada dez OSCs em atividade no país (LOPEZ, 2018). Destaca-se o grupo das associaçôes religiosas, que representa isoladamente $25,4 \%$ do total. ${ }^{26}$ Como ressaltado no estudo de Landim (2005), desde a primeira rodada das pesquisas FASFIL, em 2002, uma em cada quatro entidades (25,5\%)

26 Ver observação na nota metodológica sobre as organizações desta área. Destacamos, também, conforme assinalado no próprio relatório das FASFIL (IBGE, 2012), que este número tende a ser ainda maior, já que muitas entidades assistenciais, educacionais e de saúde, por exemplo, são também de natureza religiosa. 
compunha o grupo religião. No entanto, cumpre notar que nos últimos anos diminuiu a participação desse setor no universo geral das FASFIL, uma vez que as entidades religiosas registravam, em 1996, 30\% do total do universo ${ }^{27}$.

Nessa classificação do IPEA, há diferenças na classificação do agrupamento de desenvolvimento e defesa de direitos e interesses em comparação com o estudo das FASFIL, com um maior conjunto de subáreas dentro deste grupo. Assim, encontramos setores de outros agrupamentos alocados neste grupo, como as organizaçóes profissionais e de defesa de meio ambiente e proteção animal. Essa nova classificação elevou o percentual deste grupo, somando $41 \%$ do total, embora a pesquisa do IBGE também tenha apontado a pujança do crescimento desse tipo de associativismo. Além disso, é possível observar a tendência, já assinalada por Landim (2005), de as entidades de defesa de direitos, com destaque às de moradores, de profissionais e comunitárias, superarem as tradicionais organizaçóes que mantinham maior enraizamento na vida social - como as de cultura e recreação e de assistência social - e que passaram, com o tempo, a perder posição mais central. Cumpre notar que boa parte das organizaçóes na área dos direitos, segundo a pesquisa do IPEA (LOPEZ, 2018) foi criada a partir da década de 1990 , somando $19 \%$ do total de entidades fundadas entre 2011 e 2016 , um fenômeno relacionado ao aumento do número de ONGs e de diversas associaçôes voltadas para a defesa de direitos das minorias sociais. Vale, ainda, registrar que o trabalho de Gurza Lavalle e Barone (2015) mostrou que essas organizações - as quais, segundo eles, correspondem, a uma definição mais exigente de sociedade civil - cresceram, sobretudo, nos municípios com menor IDH.

A compreensão das variaçóes quanto às áreas de atuação ao longo do tempo também deve considerar que nem sempre estamos diante de diminuição/crescimento efetivo de associações em determinada classificação. Afinal, precisamos compreender que as associaçôes podem mudar suas designaçôes, respondendo a determinados incentivos, e por essa razão ter

27 Pesquisas atestam a pluralização de uma cultura associativa no âmbito do campo religioso. Se o protagonismo do catolicismo é perceptivel quando olhamos as mais antigas, entre as organizações religiosas mais recentes destaca-se o crescimento das pentecostais e espiritas (DOIMO, 2004; LÜCHMANN, 20I6). 
de alterar seus enquadramentos naquela classificação. Por exemplo, em algumas áreas de políticas públicas, como a assistência social e criança e adolescente, encontramos normativas que pressionaram, nas últimas décadas, as associaçóes por uma maior profissionalização e por mudanças discursivas na própria forma de nomearem seu público-alvo e missão. $\mathrm{O}$ atendimento a essas normativas é condição para que as associaçôes possam estabelecer parcerias e convênios para a prestação de serviços ou desenvolver programas vinculados a essas políticas públicas. Tais normativas, ao valorizarem a "linguagem dos direitos" em detrimento da linguagem das "obrigaçóes religiosas", podem ter funcionado como incentivo para que associaçóes religiosas passassem a se autodenominar "de defesa de direitos" (ALMEIDA, 2009).

Outros dados importantes trazidos pelos estudos do IBGE/IPEA dizem respeito aos trabalhadores das FASFIL/OSCs em relação à quantidade, à remuneração, ao gênero, ao nível de escolaridade e ao porte das associaçôes, este último identificado pelo número de trabalhadores a elas vinculados.

No estudo do IBGE, fica em evidência que, se os percentuais de pessoal ocupado diminuem conforme aumenta o ano de fundação da associação, o ritmo de expansão dos empregos formais dentro das FASFIL é superior ao de criação de entidades. Isso possibilita identificar tendências de aumento de envergadura das associaçóes em direção à profissionalização ${ }^{28}$. Um dos fatores que pode ajudar a explicar esse movimento diz respeito às exigências instituídas pelos marcos regulatórios após a Constituição de 1988, que demandaram a formalização e profissionalização de organizações sociais pertencentes a algumas comunidades de políticas públicas, como é o caso daquelas que integram a rede das políticas de assistência social e criança e

28 Entre 2006 e 2010 foram criados 292,6 mil novos empregos nas organizações da sociedade civil (15,9\%) segundo o IBGE (20I2), crescimento este que não está acompanhado do aumento do número de entidades, que ficou em 8,8\%. Com isto, o número médio de profissionais registrados por cada entidade aumentou de 6,9 pessoas em 2006 para 7,3 em 2010. Isso, aliado ao aumento da média das remunerações do pessoal ocupado, corrobora com a tese de profissionalização das associações no país. Torna-se importante também ponderar para o fato de que o estudo contempla apenas os trabalhadores assalariados com registro em carteira, de forma que um número muito grande de trabalhadores do setor sem fins lucrativos não comparece nos registros, como os freelancers ou autônomos e, não menos importantes, os trabalhadores voluntários. 
adolescente, além das áreas da educação e saúde, e que são precisamente as que mais concentram o pessoal ocupado assalariado nesse universo.

Em se tratando do sexo dos trabalhadores das FASFIL/OSCs, persiste a predominância feminina nas associaçóes. Tanto em 2010 como em 2015, as mulheres representam em torno de $65 \%$ do pessoal ocupado assalariado, com um percentual muito superior ao do restante das organizaçóes cadastradas no CEMPRE (organizaçôes públicas e privadas, lucrativas e não lucrativas), onde a participação feminina é de 42,1\% (IBGE, 2012). Os dados também mostram que há importantes diferenças a depender da área de atuação ${ }^{29}$. Em contraposição, embora a grande concentração feminina nas OSCs, os estudos apontam um quadro de desigualdades de renda considerável, em que pese uma diminuição dessa distância entre o ano de 2010 - quando as mulheres recebiam 75,2\% do salário dos homens) e de 2015 - recebiam $85 \%$ do salário dos homens.

Em relação à escolaridade, ambos os estudos mostram que nas OSCs, $33 \%$ do pessoal ocupado possuía ensino superior. O estudo do IPEA aponta que $48,8 \%$ dos trabalhadores das OSCs alcançaram o ensino médio completo. Considerando-se que, como vimos, a escolaridade é um importante recurso que permite o engajamento político, pode-se sugerir que o vínculo assalariado aqui é bastante importante para o envolvimento do grupo com um grau de escolaridade mais baixo nas FASFIL/OSCs. Importante inovação do estudo do IPEA foi trazer dados sobre o perfil racial dos trabalhadores das OSCs. O estudo mostra que 63\% das pessoas ocupadas nas associaçóes sáo brancas e 37\% negras. Encontramos, porém, variaçóes importantes entre as regióes (norte e nordeste contabilizam $73 \%$ do total de trabalhadores negros). Ainda, a maior proporção de negros encontra-se nas OSCs voltadas à assistência social e defesa de direitos.

O comparativo das pesquisas do IBGE/IPEA nos permite perceber, resumidamente, que testemunhamos, no Brasil, um crescimento (mais

29 A presença masculina predomina nos subgrupos de entidades de Esportes e Recreação, nas Associações de Moradores e nas Entidades de Desenvolvimento rural. Já nas áreas da Saúde e da Assistência social, e mais ainda Educação infantil, a presença feminina é marcante. Essas diferenças que mostram associação entre gênero e modalidade de engajamento político são também encontradas em outras esferas, a exemplo dos conselhos gestores. Estudos apontam maior incidência de mulheres nos conselhos das áreas sociais, como assistência social e criança e adolescente (LÜCHMANN; ALMEIDA; GIMENES, 20I6). 
desacelerado) acompanhado por uma maior pluralização no quadro associativo do país. Estamos assumindo, aqui, que a noção de "momento crítico" ajuda a compreender esse fenômeno. A transição de regime abriu possibilidades para a organização de novas vozes políticas no cenário nacional que, posteriormente, buscaram imprimir suas demandas nos ordenamentos legais que passaram a ser construídos, como foi o caso do processo constituinte transcorrido no final da década de 1980 .

Como desdobramento, os novos espaços de participação e as novas normativas de políticas públicas criadas no período posterior confirmaram esse processo, criando incentivos para a formalização e legalização das organizaçóes para o estabelecimento de convênios e parcerias com o Estado. A própria Reforma do Estado implementada nos anos 1990, sob o governo Fernando Henrique Cardoso, reforçou esse processo, ao fomentar a transferência da execução de determinados serviços e programas sociais para as organizaçóes da sociedade civil. Assim, o crescimento do associativismo está relacionado, nessas últimas décadas, e entre outros fatores, ao quadro de maior porosidade do Estado para a participação da sociedade civil em instituiçôes participativas, por um lado, e aos incentivos - políticos e legais - que atribuem maior responsabilidade e peso a uma atuação mais ativa da sociedade civil no desempenho de programas sociais, como atestado por estudos que apontam o aumento no número de parcerias e transferências de recursos entre governos e organizaçôes da sociedade civil, ainda que esse crescimento apresente variaçóes nas diferentes esferas federativas (LOPEZ; BARONE, 2013).

Entretanto, é necessário observar as diferenciaçôes e desigualdades internas a esse campo. Conforme pontuamos, no cenário nacional, diante desse processo de crescimento das OSCs, determinados tipos de associativismo foram promovidos, como as organizaçóes de defesa de direitos, enquanto outras perderam a centralidade, como as de cultura e recreação. As organizaçóes de saúde e educação, embora minoritárias no universo total das FASFIL/OSCs, são as que respondem pelo aumento do número de pessoal empregado nesse universo, cuja grande maioria, como as pertencentes ao grupo das religiosas e de direitos, não possui sequer um empregado formal. Por outro lado, as mulheres e os indivíduos que não contam com nível superior são grupos fortemente presentes nos quadros 
do pessoal ocupado das FASFIL/OSCs. Vejamos agora os dados relativos ao envolvimento associativo dos brasileiros e das brasileiras em uma perspectiva individual.

\section{Participação associativa em uma perspectiva individual}

Como vimos, a literatura sobre sociedade civil tem dado destaque a um crescimento do associativismo no país, em especial a partir dos anos de 1980. Os dados sobre as FASFIL/OSCs corroboram um crescimento contínuo na criação de associaçóes no território nacional nas últimas décadas. No entanto, se olharmos os dados de pesquisas de opinião de base individual, o número de pessoas que declara pertencer a alguma associação oscila no decorrer do tempo, conforme podemos visualizar na Tabela $4^{30}$.

30 Cabe salientar a diferenciação entre participação individual segundo os dados coletados por pesquisas de opinião e os dados das pesquisas IBCEE/IPEA apresentados anteriormente. No caso destas pesquisas de opinião, a natureza da participação nestas associações pode ser diversa, contemplando desde a realização de trabalho remunerado ou voluntário, além de outras possiveis formas de participação junto ao amplo e heterogêneo universo de OSCs existentes. Já os estudos do IBCE/IPEA trazem dados sobre o conjunto de trabalhadores em situação formal registrados pelas OSCs e declarados por estas junto aos órgãos competentes. 


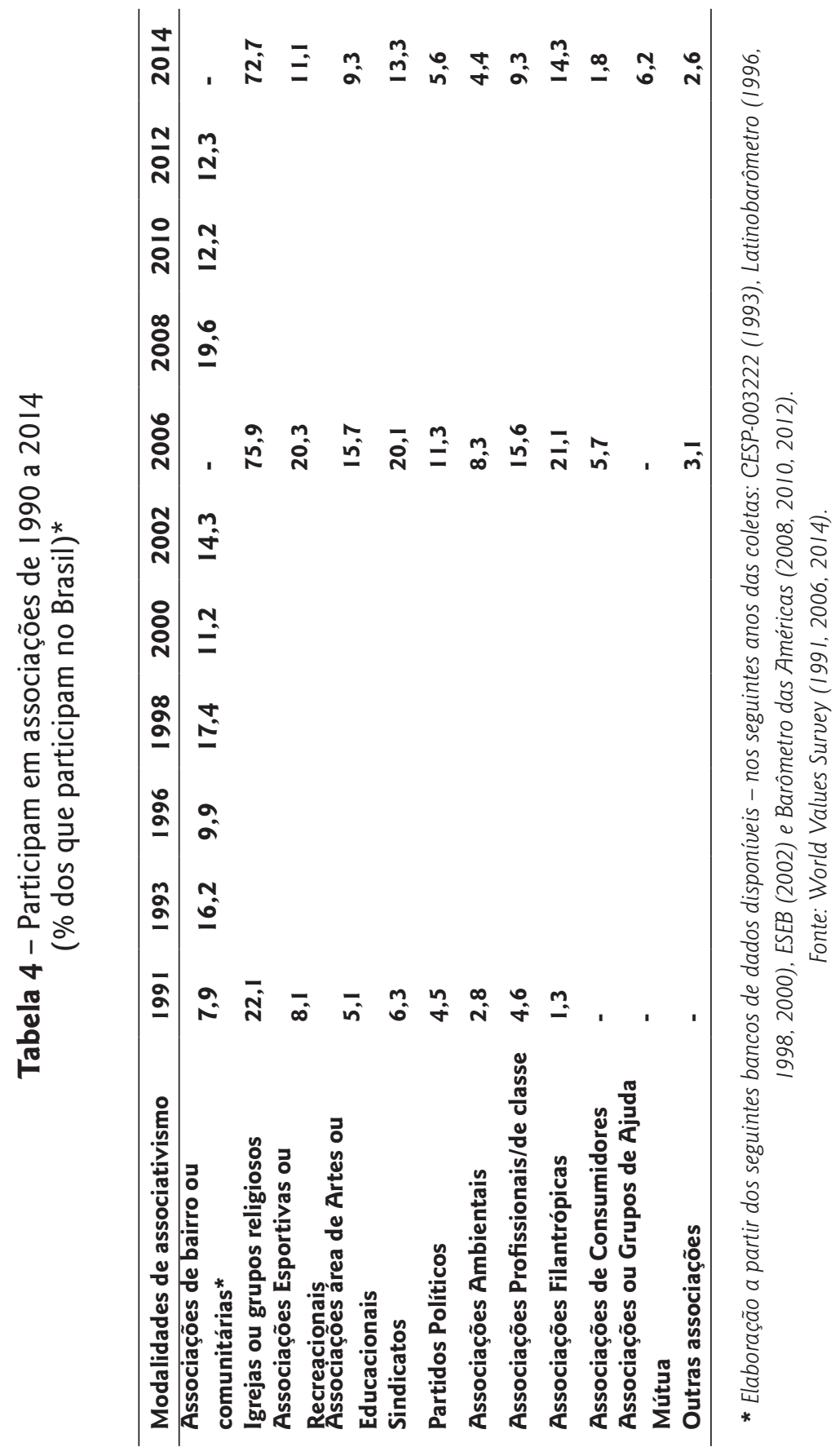


Como podemos perceber, o engajamento associativo individual tem uma curva ascendente de 1991 até 2006, quando ocorre uma diminuição dos percentuais - com exceção do engajamento em grupos religiosos -, que mantém o crescimento no período. Cumpre notar que a curva de ascensão e posterior declínio é semelhante para as associaçóes de bairro e comunitárias, cujos dados provêm de uma fonte diferente das demais modalidades associativas, o que reforça a validade do movimento geral observado no período para o engajamento dos brasileiros.

Sugerimos que a curva ascendente encontrada para o primeiro período tem relação com o fenômeno notado anteriormente do "momento crítico" brasileiro, que resultou em um crescimento e pluralização do associativismo. Assim, os dados de engajamento individual desse período refletem o crescimento verificado no tecido associativo brasileiro, traduzido no aumento no número de fundação de organizações sociais. Entretanto, esse reflexo não perdurou ao longo do período e, apesar do crescimento e da complexificação dos repertórios de participação no Brasil, nossa sociedade continua a apresentar baixos percentuais de vínculo associativo se comparados com outros países ${ }^{31}$.

Considerando os estudos que enfatizam os recursos que possibilitam o engajamento (VERBA; SCHLOZMAN; BRADY, 2012), podemos considerar que os percentuais encontrados para o Brasil estáo intimamente relacionados às fortes desigualdades sociais que marcam nossa sociedade, na qual uma grande parcela da população, ainda que com o direito de participar, náo dispóe dos recursos, subjetivos e objetivos, que se retroalimentam, considerados condicionantes da participação.

No que se refere às diferentes modalidades associativas, a Tabela 4 também permite notar que os dados para o engajamento individual refletem o peso do associativo religioso no quadro da sociedade civil brasileira, já apontado anteriormente. De forma inversa, a mesma correspondência entre a dimensão individual e a do campo das FASFIL/OSCs pode ser observada para o caso das organizaçôes de meio ambiente, corroborando o pequeno peso dessa modalidade de engajamento entre os brasileiros.

31 Se compararmos, por exemplo, com paises da América do Norte, como os EUA e Canadá, apresentando, respectivamente, 55\% e 34\% de participação, em média, conforme dados de 2010 a 2014 de World Values Survey (20/4). 
Nas demais modalidades, embora a classificação do associativismo utilizada nas pesquisas do IBGE/IPEA seja distinta das contempladas nas pesquisas de opiniáo pública, percebemos, de forma geral, que há algumas correspondências entre as fontes em termos dos padróes de engajamento individual, em que pese a queda generalizada no ano de 2014. As associaçôes vinculadas ao mundo do trabalho cresceram nas duas dimensóes observadas, da mesma forma que o associativismo de bairro, se compararmos com o início da década de 1990, o que corrobora, em alguma medida, os dados das FASFIL/OSCs, que alocam esse associativo na classificação das organizaçóes de defesa de direitos (ver Tabela 3), tipologia que também apresentou crescimento na dimensão institucional.

Considerando os dados a partir do recorte de sexo, verificamos que há variaçóes relativamente pequenas no engajamento de mulheres e homens, mas com leve preponderância delas sobre eles a partir de 2006, conforme a Tabela 5, a seguir. Há, contudo, um dado muito importante a ser notado aqui: aumentou, no período, o número de mulheres engajadas em mais de uma modalidade associativa. É digno de nota lembrar que os dados FASFIL/IPEA apontaram para um forte envolvimento feminino nos seus quadros. Ainda que o vínculo político não possa ser confundido com o vínculo profissional, é plausível supor que o leve aumento de mulheres engajadas em associaçóes, verificado nos dados da participação individual, deva refletir, em alguma medida, o crescimento verificado nas organizaçóes para o período. Assim, podemos considerar que o crescimento das FASFIL/OSCs impactou seletivamente o engajamento individual, abrindo mais oportunidades para o engajamento de mulheres.

Tabela 5 - Participam de Associações segundo Sexo, Escolaridade e Faixa Etária

\begin{tabular}{cccccc}
\hline \multicolumn{2}{c}{ Sexo } & \multicolumn{2}{c}{ Escolaridade } & \multicolumn{2}{c}{ Faixa etária } \\
\hline Mulheres & Homens & Analfabeto & $0.5 \%$ & 18 a 25 anos & $15,5 \%$ \\
$82,5 \%$ & $78,3 \%$ & $\begin{array}{c}\text { Ensino básico completo/incompleto } \\
\text { Ensino secundário completo/ } \\
\end{array}$ & $\begin{array}{c}\text { incompleto } \\
\text { Ensino superior completo/ } \\
\text { incompleto }\end{array}$ & 26 a 35 anos & $19,7 \%$ \\
& & $52.1 \%$ & 36 a 45 anos & $19,9 \%$ \\
& & & 55 e acima 55 anos & $20,4 \%$ & $24,5 \%$ \\
\hline
\end{tabular}

Fonte: World Values Survey (20/4). 
Cabe ressaltar que, se os estudos sobre participação apontam que a escolaridade é um importante determinante para o engajamento político, chama a atenção o percentual significativo de brasileiros engajados com ensino básico completo/incompleto. $\mathrm{Na}$ onda de 2014, os engajados nesse grau de escolaridade somaram 44,7\%, conforme apresentado na Tabela 5. Também aqui é possível sugerir que este dado possa ser mais bem compreendido a partir do cruzamento com os dados das FASFIL/OSCs, que acusam um importante peso de indivíduos sem nível superior nos seus quadros. Reforçando essa hipótese, lembramos que houve, no referido período, um crescimento do associativismo no campo da defesa de direitos, principalmente, em municípios com baixo IDH. Sugerimos, assim, que o crescimento dessas associações possa ter servido como uma oportunidade de engajamento a indivíduos com grau menos elevado de escolarização.

No que diz respeito ao menor engajamento dos mais jovens, vale notar duas dimensóes desse fenômeno. Por um lado, como mostraram Okado e Ribeiro (2015), as diferenças entre a participação política do jovem e do adulto estáo relacionadas aos efeitos inerentes ao ciclo de vida dos indivíduos, na medida em que os recursos disponíveis para o engajamento político variam ao longo de sua vida. Disponibilidade de tempo livre e de renda, por exemplo, são recursos que abrem ou restringem as possibilidades de engajamento político para jovens e adultos. Os jovens tenderiam a um tipo de engajamento que exige menos recursos financeiros e mais recursos de tempo livre, em contraste com o indivíduo adulto. Por outro lado, alguns estudos têm apontado para novas formas de expressão política da juventude, como o cyberativismo. O estudo de Nunes (2014) sobre os protestos de 2013, por exemplo, distingue o que ele denomina "geração de junho" da "geração da redemocratização" em termos de socialização política. Para o autor, essa última foi forjada na resistência à ditadura e deu vida às principais organizaçóes e a movimentos de esquerda que daí resultaram, como o Partido dos Trabalhadores (PT) e Movimento dos Sem Terra (MST). A "geração de junho" seria a protagonista típica não mais de movimentos sociais no sentido tradicional, mas de acontecimentos, que captam e expressam um mal estar difuso, a exemplo também da primavera árabe, do Occupy dos Estados Unidos, do Diren Gezi da Turquia. Em suma, se os jovens já tendem a tipos de engajamento menos exigentes em 
termos de recursos, o cyberativismo pode ter se apresentado como uma modalidade atraente para a sua expressão política, se comparado com o vínculo com associaçóes.

Finalmente, embora haja dificuldades para construirmos análises mais robustas diante desses dados, podemos concluir que o caso brasileiro sugere a necessidade de algumas mediações para os estudos que diferenciam participação material e pós-material. Como vimos, predomina, no país, um padrão associativo que está voltado para as dimensóes materiais, com baixos percentuais de envolvimento em modalidades consideradas pós-materiais, a exemplo do meio ambiente ${ }^{32}$ e de direitos do consumidor. No entanto, testemunhamos, também para o caso brasileiro, um crescimento de organizaçóes voltadas à defesa de direitos, o que inclui àquelas dedicadas aos direitos de minorias - como mulheres, população negra e indígenas -, e que ocorreu, principalmente, conforme explicam Gurza Lavalle e Barone (2015), em municípios mais pobres. Assim, podemos considerar que, em sociedades marcadas por fortes desigualdades sociais, como a nossa, a organização e vocalização de demandas pelos direitos desses grupos parece exigir de maneira mais enfática uma articulação com as demandas pela distribuição de bens materiais, o que implica questionar a pertinência da clivagem material e pós-material para esta realidade.

Diante desses dados, podemos afirmar, resumidamente, que os percentuais de engajamento individual no Brasil são comparativamente baixos se náo considerarmos a forte presença das atividades religiosas - em relação a outras realidades, o que destoa do crescimento verificado no período para as organizaçôes da sociedade civil. Sugerimos, entretanto, que esse crescimento impactou seletivamente o engajamento individual, proporcionado o aumento de mulheres e de indivíduos com níveis de escolarização mais baixos na composição dos engajados em associaçóes no país.

Mas, fundamentalmente, podemos sugerir que a discrepância verificada entre o crescimento do campo associativo e as oscilaçôes verificadas na dimensão individual, que não acompanhou, de forma linear, aquele

32 Estudos sobre o movimento ambientalista no Brasil têm indicado que esse campo de atuação associativa apresenta algumas características que limitam a sua expansão, com destaque à sua profissionalização (OLIVEIRA, 20I6). 
crescimento, pode ser entendida levando-se em consideração que o associativismo que cresceu no período esteve dedicado, sobretudo, às exigências de maior profissionalização, requisito das novas oportunidades de participaçáo abertas junto às políticas públicas. Ainda que contando com poucos recursos, boa parte das organizaçóes do período buscou se adequar a essa realidade, distanciando-se das atividades vinculadas propriamente à mobilização. Em muitos casos, a sobrecarga envolvida nas funções representativas junto às instituiçóes participativas, como os conselhos, e/ou executivas, no atendimento às demandas sociais, também entrou em tensão com a capacidade de as organizaçôes desenvolverem trabalhos de mobilização, o que ampliaria seus públicos participativos (LÜCHMANN, 2011). Convém também registrar o predomínio e o aumento de associaçôes de pequeno porte. Essas considerações ajudariam a entender as razóes pelas quais o crescimento no número de associaçóes não tem se refletido, pelo menos na mesma intensidade e de forma abrangente, nos níveis de engajamento individual.

\section{Considerações finais}

O trabalho objetivou apresentar, a partir de diferentes bases de dados, um panorama da participação associativa dos brasileiros considerando duas dimensóes, quais sejam: a dimensão referente ao volume e a características do tecido associativo; a dimensão do engajamento dos indivíduos em associações. $\mathrm{O}$ cruzamento da participação individual e organizacional buscou avaliar a existência de uma correlação entre o aumento do número de organizaçóes da sociedade civil e o aumento ou o incremento da participação associativa dos brasileiros e brasileiras.

Sugerimos que o crescimento e a pluralização do associativismo verificados nas pesquisas FASFIL/OSCs estiveram relacionados ao "momento crítico" experimentado pela sociedade brasileira no período de transição de regime, que foi seguido de um quadro de maior porosidade do Estado para a participação da sociedade civil em instituições participativas, por um lado, e de incentivos - políticos e legais - que atribuíram maior responsabilidade e peso a uma atuação mais ativa da sociedade civil no desempenho de programas sociais. 
Vimos também que, embora ainda encontremos um predomínio das organizaçóes religiosas, os dados apontam para uma maior diversificação do cenário associativo, em especial pelo crescimento das associaçóes que atuam na área da defesa de direitos e interesses - o que corrobora o argumento do "momento crítico" -, e que implicou alguns pontos de inflexão importantes, como a Constituição de 1988, colocando na agenda dos atores políticos e sociais as demandas por direitos de cidadania.

Identificamos, também, a forte presença de mulheres e de indivíduos menos escolarizados nos quadros ocupacionais das organizaçóes. Houve, ainda, destaque para o porte dessas organizações, uma vez que a grande maioria não possui sequer um empregado formal. Esse predomínio de organizaçóes de pequeno porte pode ser outra chave para a compreensão da não ocorrência de uma correlação direta e imediata entre o aumento do número de organizaçóes e o aumento,ou o incremento da participação associativa dos brasileiros e brasileiras.

Além disso, ainda que contando com poucos recursos, ao contrário das tarefas de mobilização, boa parte das organizaçóes criadas no período dedicou-se a responder às exigências de profissionalização e a exercer funçóes representativas em função das oportunidades abertas de participação junto ao Estado. Esse perfil de atuação dificulta e entra em tensão com as tarefas de mobilização, dedicadas à ampliação dos públicos participativos.

O destaque a considerar aqui é o de que, se por um lado podemos afirmar que, no plano geral, o crescimento de associaçóes não se refletiu de forma expressiva e abrangente no número de indivíduos engajados, por outro lado, esse reflexo ocorreu de forma seletiva. Assim, em consonância com o modelo do voluntarismo cívico, as organizaçóes criadas, em especial no campo da defesa de direitos, podem estar operando como estruturas de engajamento político para setores da população desprovidos de outros recursos, também considerados centrais para o entendimento do fenômeno - complexo e variado - da participação política.

Diante disso, podemos constatar que, apesar da importância da dependência de uma trajetória marcada por fortes desigualdades sociais, o crescimento das FASFIL/OSCs indica uma dinamicidade que, impactada por "momentos críticos" - por exemplo, o período da abertura política, da 
Constituição de 1988 e das políticas de "governança” implementadas nas décadas seguintes -, tem, seletivamente, apresentado implicaçôes no plano do engajamento associativo individual, em especial no tocante à inclusão de mulheres e indivíduos com menos recursos.

Finalmente, cabe destacarmos que o crescimento e a pluralização do campo associativo observado no período carregam diferenciaçóes internas que merecem atenção. Os dados encontrados apontam para importantes desigualdades e diferenciaçóes, tanto regionais quanto de propósitos e de recursos, levantando vários desafios analíticos nos estudos de âmbito quantitativo.

\section{Referências}

ALMEIDA, C. C. R. O marco discursivo da participação solidária e a redefiniçáo da questáo social: construção democrática e lutas políticas no Brasil pós 90. 2006. 207 p. Tese (Doutorado em Ciências Sociais) - Programa de Pós-Graduação em Ciências Sociais, Universidade Estadual de Campinas, Campinas, 2006.

ALMEIDA, C. C. R. Conselhos gestores e regulação: a assistência social em tempos de transição. Política \& Sociedade, v. 8, n. 15, p. 251-269, 2009.

ALMEIDA, R; D’ANDREA, T; DE LUCCA, D. Situações periféricas: etnografia comparada de pobrezas urbanas. Novos estud. CEBRAP, São Paulo, n. 82, p. 109- 130, nov. 2008.

AVRITZER, L. Um desenho institucional para o novo associativismo. Lua Nova, n. 39, p. 149$174,1997$.

CHAMBERS, S.; KOPSTEIN, J. Bad Civil Society. Political Theory, v. 29, n. 6, p. 837-865, dec. 2001.

COHEN J.; ROGERS, J. Associations and Democracy. London: Verso, 1995.

DALTON, R.; WELZEL, C. (Ed.). The Civic Culture Transformed: From Allegiant To Assertive Citizens. New York: Cambridge University Press, 2014.

DOIMO, A. M. Pluralidade religiosa à brasileira, associativismo e movimentos sociais em São Paulo. In: AVRITZER, L. (Org.). A participaçáo em Sáo Paulo. São Paulo: Editora UNESP, 2004. p. 123-196.

FUNG, A. Associations and Democracy: Between Theories, Hopes, and Realities. Annual Review of Sociology, Palo Alto, v. 29, p. 515-539, 2003.

GARCÍA-ESPÍN, P; GANUZA, E. Participatory Skepticism: Ambivalence and Conflict in Popular Discourses of Participatory Democracy. Qualitative Sociology, v. 40, n. 4, p. 425-446, 2017. 
Dsiponível em: https://link.springer.com/article/10.1007/s11133-017-9367-6\#citeas. Acesso em: 10 ago. 2018.

GURZA LAVALLE, A.; BARONE, L. S. Conselhos, associações e desigualdades. In. ARRETCHE, M. (Org.). Trajetória das desigualdades: como o Brasil mudou nos últimos cinquenta anos. São Paulo: UNESP, 2015. p. 51-76.

GURZA LAVALLE, A; SZWAKO, J. Sociedade civil, Estado e autonomia: argumentos, contraargumentos e avanços no debate. Opiniáo Pública, v. 21, p. 157-187, 2015.

INGLEHART, R.; WELZEL, C. Modernization, Cultural Change, and Democracy: The Human Development Sequence. New York: Cambridge University Press, 2005.

INSTITUTO BRASILEIRO DE GEOGRAFIA E ESTATÍSTICA (IBGE). Fundaçóes Privadas e Associaçóes sem Fins Lucrativos no Brasil 2010. Estudos e Pesquisas Informação Econômica, n. 20. Rio de Janeiro: IBGE, 2012.

JOHNS HOPKINS UNIVERSITY. 2018. Disponível em: http://ccss.jhu.edu. Acesso em: 10 ago. 2018.

LANDIM, L. Múltiplas Identidades das ONGs. In: HADDAD, S. (Org.). ONGs e Universidades. Desafios para a cooperação na América Latina. São Paulo: Fundação Petrópolis, 2002. p. 17-50.

LANDIM, L. Associações no Brasil: comentários sobre dados oficiais recentes. Democracia Viva, Rio de Janeiro, v. 28, p. 76-85, 2005.

LOPEZ, F. G. (Org.). Perfil das organizaçóes da sociedade civil no Brasil. Brasília: IPEA, 2018.

LOPEZ, F. G.; BARONE, L. As entidades sem fins lucrativos e as políticas públicas federais: tipologia e análise de convênios e organizaçóes (2003-2011). In: INSTITUTO DE PESQUISA ECONÔMICA (IPEA). Coleçáo Textos para discussáo - 1896. Brasília: IPEA, 2013.

LUCHMANN, L. H. H. Associações, participação e representação: combinaçóes e tensôes. Lua Nova, n. 84, p.141-174, 2011.

LÜCHMANN, L. H. H. Modelos contemporâneos de democracia e o papel das associaçóes. Revista de Sociologia e Política, v. 20, p. 59-80, 2012.

LÜCHMANN, L. H. H. Abordagens teóricas sobre o associativismo e seus efeitos democráticos. Revista Brasileira de Ciências Sociais, v. 29, p. 159-178, 2014.

LÜCHMANN, L. H. H. Associaçóes e democracia. Um estudo em Florianópolis. Florianópolis: Editora da UFSC, 2016.

LÜCHMANN, L. H. H; ALMEIDA, C.; GIMENES, E. Gênero e representação política nos Conselhos Gestores no Brasil. Dados, Rio de Janeiro, v. 59, n. 3, p.789-822, 2016.

MACPHERSON, C. B. A democracia liberal: origens e evolução. Rio de Janeiro: J. Zahar, 1978.

NUNES, R. Geração, acontecimento, perspectiva. Pensar a mudança a partir do Brasil. Nueva Sociedad - Especial em Português, n. 12, p. 14-26, 2014. 
Associativismo no Brasil contemporâneo: dimensões institucionais e individuais) | Lígia Helena Hahn Lüchmann; Carla Almeida; Luana do Rocio Taborda

OKADO, L. T. A.; RIBEIRO, E. Condiçâo juvenil e participação política no Brasil. Paraná Eleitoral, v. 4, n. 1, p. 53-78, 2015.

OLIVEIRA, M. S. Movimento para as instituiçóes: ambientalistas, partidos políticos e a liderança de Marina Silva. 2016. 303 f. Tese (Doutorado em Ciência Política) - Programa de Pós-Graduação em Ciência Política, Universidade de Brasília, Brasília, 2016.

RIBEIRO, E. A.; BORBA, J. Participaçáo política na América Latina. 1. ed. Maringá: EDUEM, 2015.

SALAMON, L. M. Putting the Civil Society Sector on the Economic Map of the World. Annals of Public and Cooperative Economics, v. 81, n. 2, p. 167-210, 2010.

SALAMON, L. M.; SOKOLOWSKI, S. W.; HADDOCK, M. Explaining Civil Society Development. A Social Origins Approach. Baltimore: Johns Hopkins University Press, 2017.

SANTOS, W. G. Razóes da desordem. Rio de Janeiro: Rocco, 1993.

SCHERER-WARREN, I. Associativismo civil em Florianópolis - da ditadura à redemocratização. In: SCHERER-WARREN, I.; CHAVES, I. M. (Org) Associativismo civil em Santa Catarina. Trajetórias e tendências. Fpolis: Ed. Insular, p. 21-45, 2004.

TEIXEIRA, A. C. C. Identidades em construção. As Organizaçóes Não-Governamentais no processo brasileiro de democratização. São Paulo: Annablume, 2008.

TERUYA, C.; HSER, Y. Turning Points in the Life Course: Current Findings and Future Directions in Drug Use Research. Curr Drug Abuse Rev, v. 13, n. 3, 189-195, sep. 2010.

TURABIAN, J. Women and Transitions: The Theory of Turning Points. Women's Health Care, v. 6, issue 5, p. 1-2, 2017.

SCHLOZMAN, K. L.; VERBA, S.; BRADY, H. E. The Unheavenly Chorus. Unequal Political Voice and the Broken Promise of American Democracy. Princeton: Princeton University Press, 2012.

VERBA, S; SCHLOZMAN, L. K.; BRADY, H. E. Voice and Equality: Civic Voluntarism in American Politics. Cambridges: Havard Press, 1995.

VIEIRA, L. Os argonautas da cidadania. A sociedade civil na globalização. Rio de Janeiro: São Paulo: Record, 2001.

WARREN, M. Democracy and Association. Princeton: Princeton University, 2001.

WORLD VALUES SURVEY. World Values Survey: Round Two - Country-Pooled Datafile Version: www.worldvaluessurvey.org/WVSDocumentationWV2.jsp. Madrid: JD Systems Institute. . 1991. Disponível em: www.worldvaluessurvey.org. Acesso em: 22 fev. 2019.

WORLD VALUES SURVEY. World Values Survey: Round Five - Country-Pooled Datafile Version: www.worldvaluessurvey.org/WVSDocumentationWV5.jsp. Madrid: JD Systems Institute. 2006. Disponível em: www.worldvaluessurvey.org. Acesso em: 22 fev. 2019. 
WORLD VALUES SURVEY. World Values Survey: Round Six - Country-Pooled Datafile Version: http://www.worldvaluessurvey.org/WVSDocumentationWV6.jsp. Madrid: JD Systems Institute.2014. Disponível em: www.worldvaluessurvey.org. Acesso em: 10 ago. 2018.

YOUNG, I. M. Social Groups in Associative Democracy. In: COHEN, J.; ROGERS, J. (Ed.). Associations and Democracy. London:Verso, 1995. p. 207-2013.

\section{Associativism in Contemporary Brazil: Institutional and Individual Dimensions}

\section{Abstract}

This article analyzes continuities and changes in the patterns of associative participation in Brazil from two analytical perspectives: the dimension related to the volume and characteristics of the associative tissue, and the dimension of the size of the individual's engagement in associations. The first presents the recent evolution of associativism in the country, measured by the quantity, profile and scope of associations. In the second, the evolution of participation on the level of individual engagement is considered through the assessment of the number of individuals who claim to take part in associations. This assessment is based on public opinion research data from the World Values Survey project and from Fundações Privadas e Associações Sem Fins Lucrativos no Brasil (FASFIL)/Instituto Brasileiro de Geografia e Estatística (IBGE) and Profile of Social Society Organizations of Instituto de Pesquisa Econômica Aplicada (IPEA) reports. The data allows for the suggestion that, in the last decades, Brazil witnessed an important growth of associations founded - reflected in the greater internal diversification of this universe - while the number of engaged individuals did not follow this evolutionary growth. We suggest that the expansion of associativism was only selectively reflected in the level of individual engagement, and that the specific profile of associations that found growth-enhancing territory in the period, of a more professional nature, helps to understand the difference pointed out in the two dimensions.

Keywords: Associativism. Civil Society. Political Participation. Associative Engagement. Democracy. 